\title{
Water-Resources Activities of the Kentucky District, FY 1995-96
}

The U.S. Geological Survey (USGS) is the principal Federal earth-science agency dedicated to collecting, analyzing, interpreting, publishing, and disseminating information about the Nation's energy, land, mineral, and water resources. The USGS is unique among Government organizations because it has neither regulatory nor developmental authority - its sole product is information. The primary role is that of a scientific organization concerned with providing credible, relevant, impartial, and timely information to all interested parties.

The USCS was established by an act of Congress on March 3, 1879, to provide a permanent Federal agency to conduct systematic and scientific classification of the public lands and examination of the geological structure, mineral resources, and products of national domain. Since 1879, the research and fact-finding role of the USGS has both grown and evolved to meet the changing needs of the

Nation.

Fulfilling the mission of the USCS is provided in major part by the Water Resources Division (WRD). WRD supplies the hydrologic information and understanding needed for the optimum utilization and management of the Nation's water resources for the overall benefit of the people of the United States. The USGS Kentucky District investigates the occurrence, distribution, quantity, movement, and chemical and biological quality of Kentucky's surface and ground water. Water-resources activities of the Kentucky District include

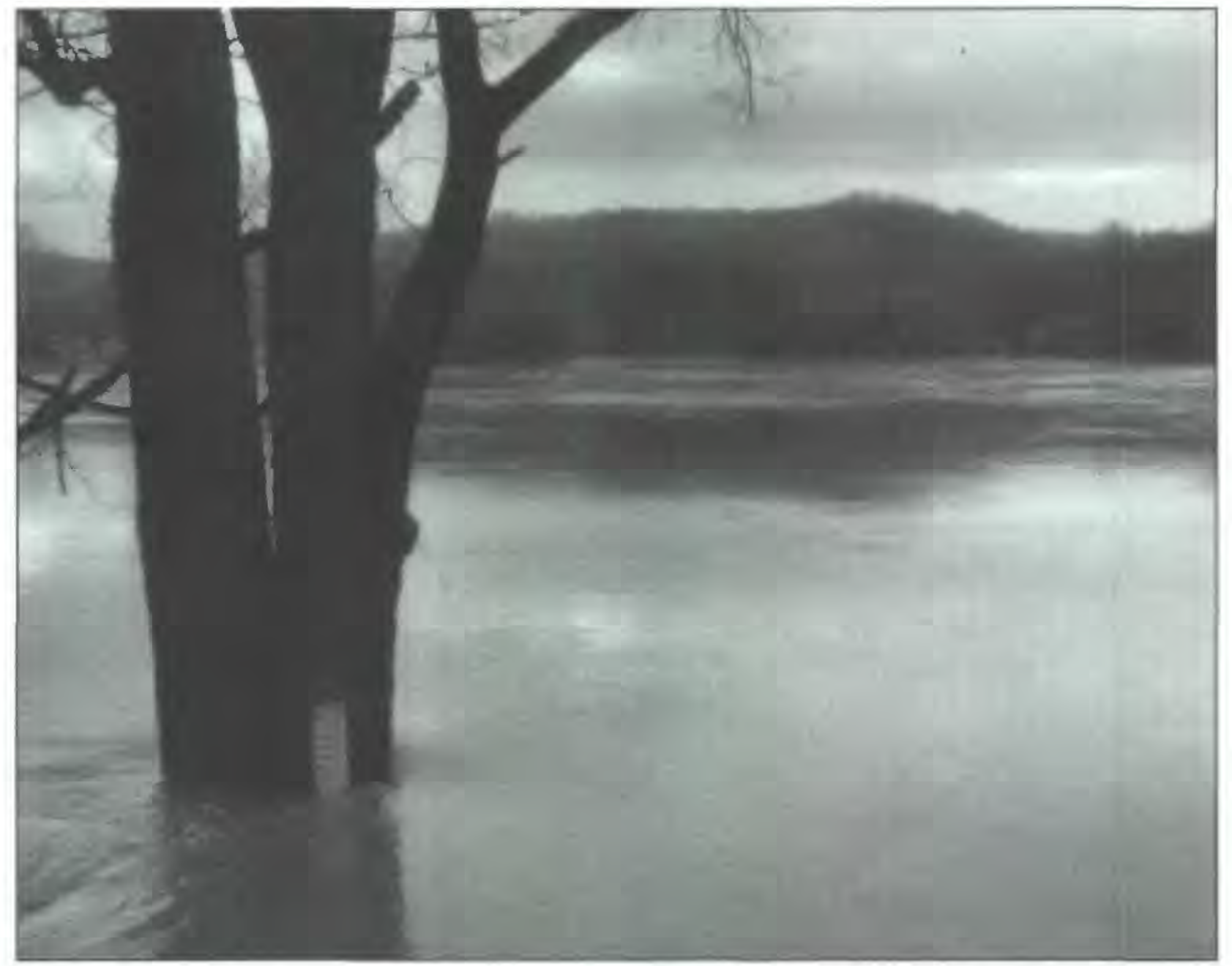

Flood waters on the Kentucky River completely covered lock 2 in December 1990. The Kentucky River crested at 36.25 feet -13 feet above flood stage.

(1) maintenance and analysis of long-term (since 1898) quantitative and qualitative data for streams, reservoirs, estuaries, and ground water; and (2) shorter-term interpretative investigations of specific waterresources issues on a local, State, regional, and national level. Such investigations include brine contamination from oil and gas development, nonpoint-source contamination in ground water, and trace-element contamination in streams and reservoirs.
MISSION of Kentucky WRD: The mission of the Kentucky District is to provide the hydrologic information and understanding needed for the optimum utilization and management of the Nation's water resources.

VISION of Kentucky WRD: We are leaders in providing timely and accurate waterresources and related earthscience information for current and future generations. 


\section{District Organization}

Water-resources activities of the Kentucky District are conducted by a highly trained staff that consists of more than 40 hydrologists, geologists, engineers, hydrologic technicians, and a variety of support personnel. The District maintains three offices: the District office in Louisville and field offices in Paducah and Williamsburg.

\section{Louisville District Office} 9818 Bluegrass Parkway Louisville, KY 40299

Randolph B. See, District Chief (502) 493-1900

\section{Paducah Field Office \\ 501 Broadway, Room M-17 \\ Paducah, KY 42001}

Alan C. Brown, Field Office Chief (502) 443-1252

\section{Williamsburg Field Office \\ P.O. Box 1028 \\ Williamsburg, KY 40769}

F. Dave Byrd, Field Office Chief (606) 549-2406

For information on specific programs, please contact the Kentucky District office in Louisville:
Telephone
(502) 493-1900
Internet:

$$
\text { dc_ky@usgs.gov }
$$

\section{Cooperative Program}

Inclusion in the Federal-State Cooperative Program is considered when a proposed jointly funded study is mutually advantageous to the USGS and the Commonwealth or local agency or government. Cooperative funding is provided to those projects which present significant opportunities to transfer or regionalize hydrologic information, to expand our understanding of hydrologic systems and processes, or to develop new tools or methods for studying the same.

\section{Funding Sources}

Financial support for District hydrologic-data collection and investigations comes from three sources:

(1) Federal-State Cooperative Program (COOP), where funds from local, regional, or Commonwealth agencies and governments are matched with USGS funds;

(2) reimbursable funding from other Federal agencies (OFA) such as the U.S. Army Corps of Engineers and the U.S. Environmental Protection Agency; and (3) direct congressional appropriations to the USCS (Federal) for hydrologic networks and investigative programs.

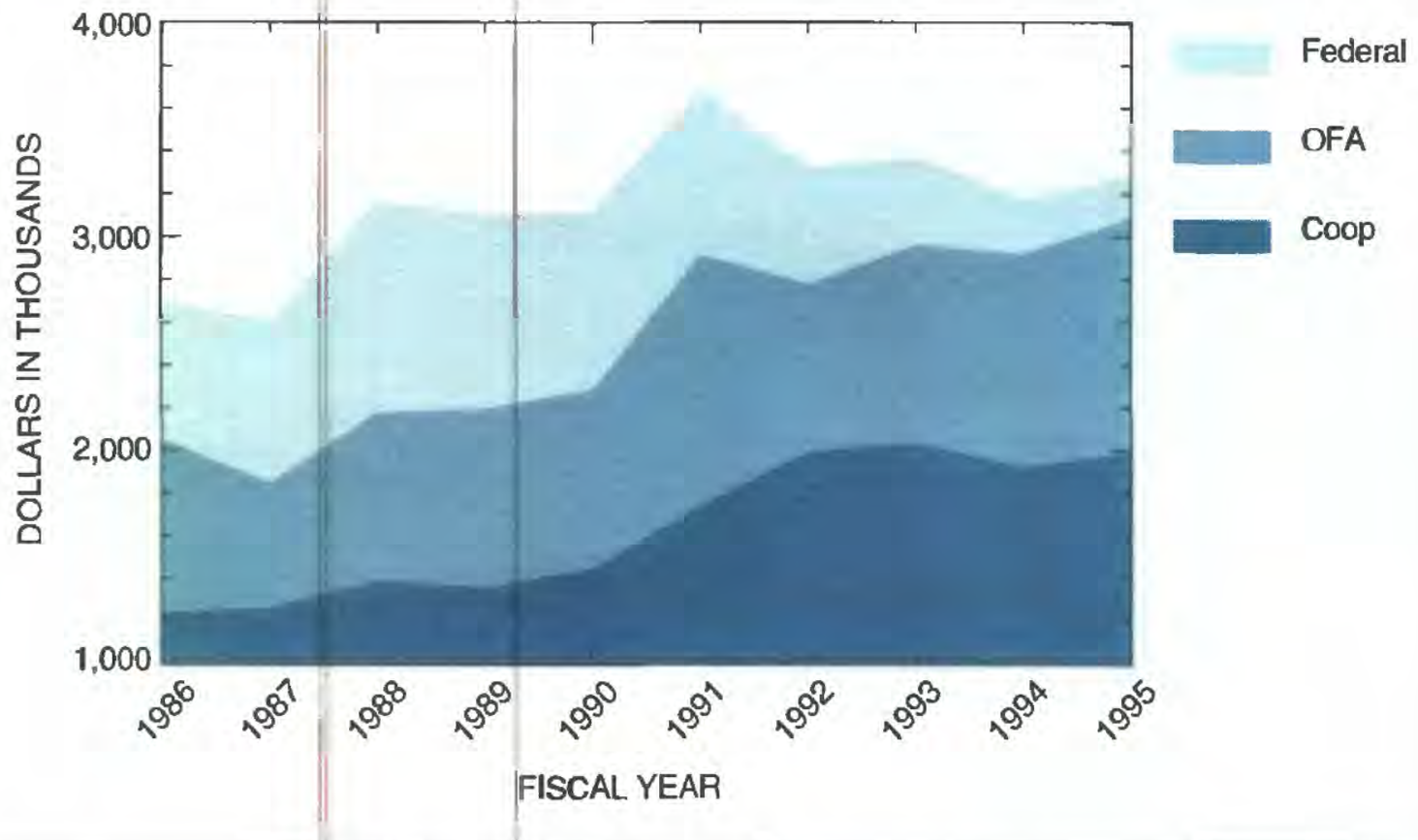

These cooperative, jointly funded programs are revilewed and renegotiated annually to ensure that they are responsive to the needs of the Commonwealth and localities, and also to the national priorities of the USGS. Current agencies or governments supporting cooperative waterresources programs in Kentucky include-

Bullitt County, Kentucky Carroll County Water Supply

Planning Board

City of Elizabethtown

City of Georgetown

City of Louisville

Glasgow Water Company
Kentucky Cabinet for Human Resources, Department of Health Services

Kentucky Natural Resources and Environmental Protection Cabinet, Department of Environmental Protection - Division of Water - Division of Waste Management

Kentucky Office of Geographic Information Systems

Kentucky Regional Planning and Development Agency

Kentucky River Authority

Kentucky Utilities Company

Louisville, and Jefferson County Metropolitan Sewer District University of Louisville 


\section{HYDROLOGIC-DATA COLLECTION}

Hydrologic data, also referred to as basic data, are critical to the investigations conducted by the USGS and other researchers. The basic data programs conducted by the District provide streamflow, ground-water level, sediment, precipitation, waterquality, and water-use information essential for the utilization and management of the Commonwealth's water resources. The District's hydrologic data are available on computer disks and are published in the USGS annual data report titled "WaterResources Data for Kentucky" and in other USGS publications.

\section{New Program}

\section{Evaluation of Ground-Water Quality of the Ohio River Alluvial Aquifer in Jefferson County, Kentucky}

Cooperator: City of Louisville

Purpose: A systematic collection and reporting of ground-water quality data are necessary to assess existing and future water-quality conditions in the Ohio River alluvial aquifer.

Goals:

- Compile existing ground-water quality data

- Install a network of monitoring wells and conduct a systematic sampling program

- Create and maintain a ground-water quality data base

- Disseminate information through geographical information system products

- Document variations and trends in the quality of ground water

\section{Continuing Programs}

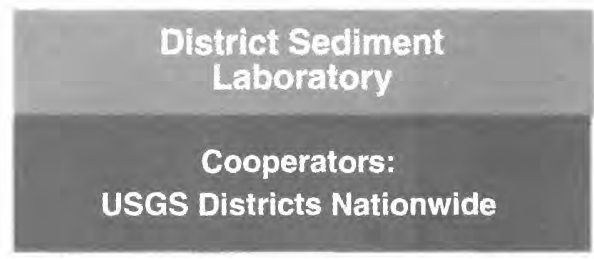

Sediment plays an important role in the transport of constituents in surface-water and karst-aquifer systems. The Kentucky District operates a laboratory capable of suspended-sediment analysis to define suspended-sediment and streambedsediment loads.

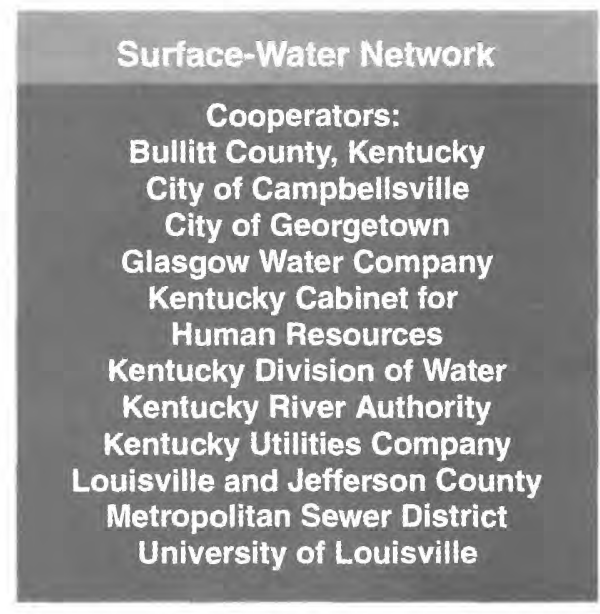

The Kentucky District currently operates and maintains 118 gaging stations of which 80 provide nearreal-time stage data, 81 provide daily discharge data, 76 provide precipitation data, and periodic water-quality sampling is done at 31 sites. Data are also collected at six crest-stage/peakflow stations and eight special studies stations.

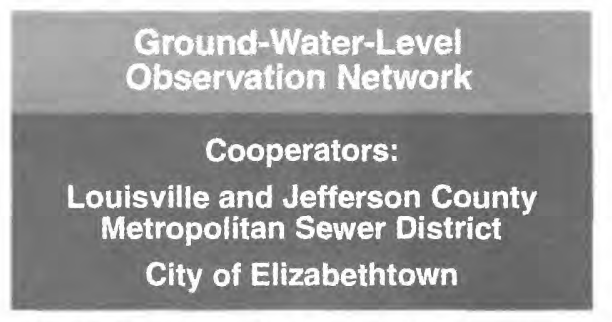

The Kentucky District maintains a network of observation wells to provide long-term ground-water-level data. The ground-water resource information is useful to measure the effects of human activities and natural events and to assist in the prediction of future water supplies and groundwater management. The network consists of 20 wells located throughout the Commonwealth with an additional 63 monitoring wells in Jefferson County.

\section{Surface-Water-Quality Monitoring Network}

The Kentucky District monitors two sites on the Ohio River as part of the National Stream-Quality Accounting Network (NASQAN). The NASQAN program provides a National data base designed to define and monitor the physical, chemical, and biological quality of surface streams for the planning, management protection, and assessment of the surface-water resources of the country.

\section{Chemical Quality of Precipitation}

The Kentucky District participates in the National Atmospheric Deposition Program (NADP) of the USGS. The NADP supports research on atmospheric deposition and its effects on water resources, agriculture, and forest lands.

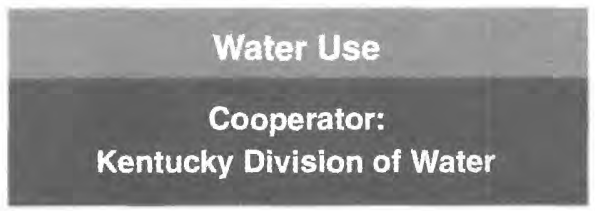

Information concerning where, how, and in what quantities water is being used is gathered and compiled as part of a computerized statewide water-use data base. Water-use information for the Commonwealth is published every 5 years as part of a National water-use report.

\section{... collecting hydrologic data critical to scientific investigations}




\section{Water-Resources Activities of the Kentucky District}
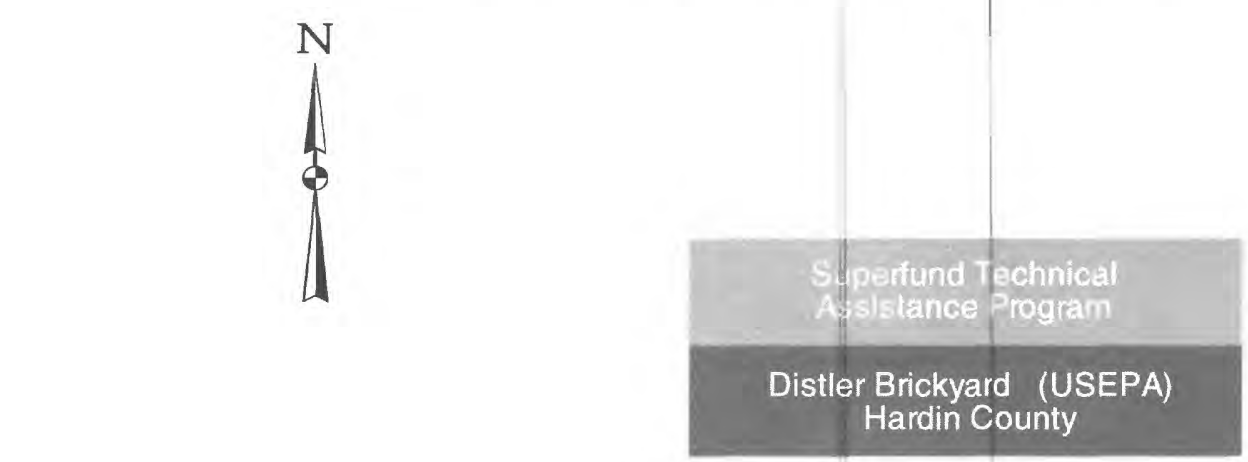

Louisville District Office

Randolph B. See, District Chief

Paducah Field Offce Alan C. Brown, Chief
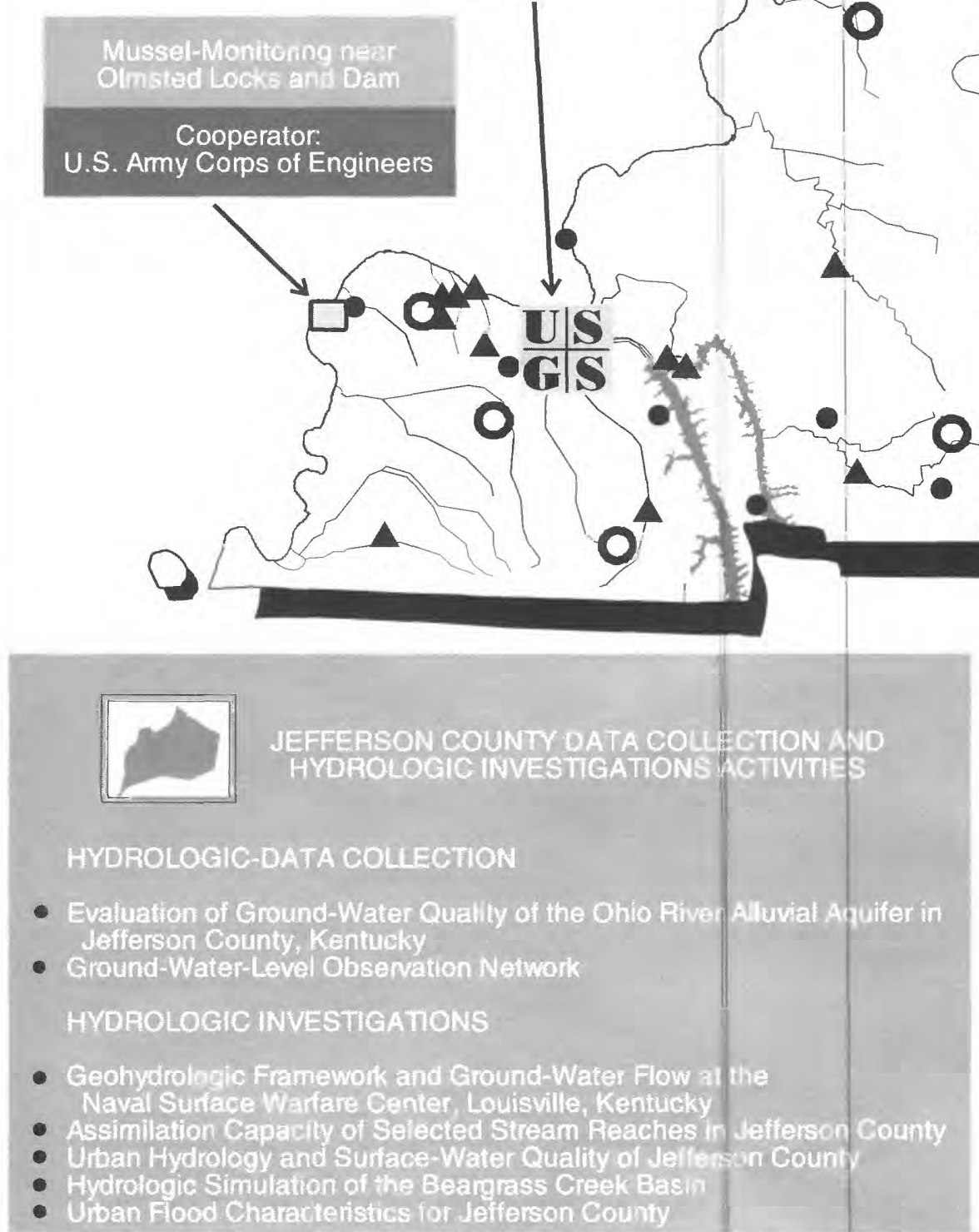

\section{$\frac{\mathbf{U} \mid \mathbf{S}}{\mathbf{G}}$ Sentucky}

A Surface-Water Stre

- Ground-Water-Leve

National Stream-Q। (NASQAN) Gage

- National Atmosphe Gage

- Precipitation Gage 


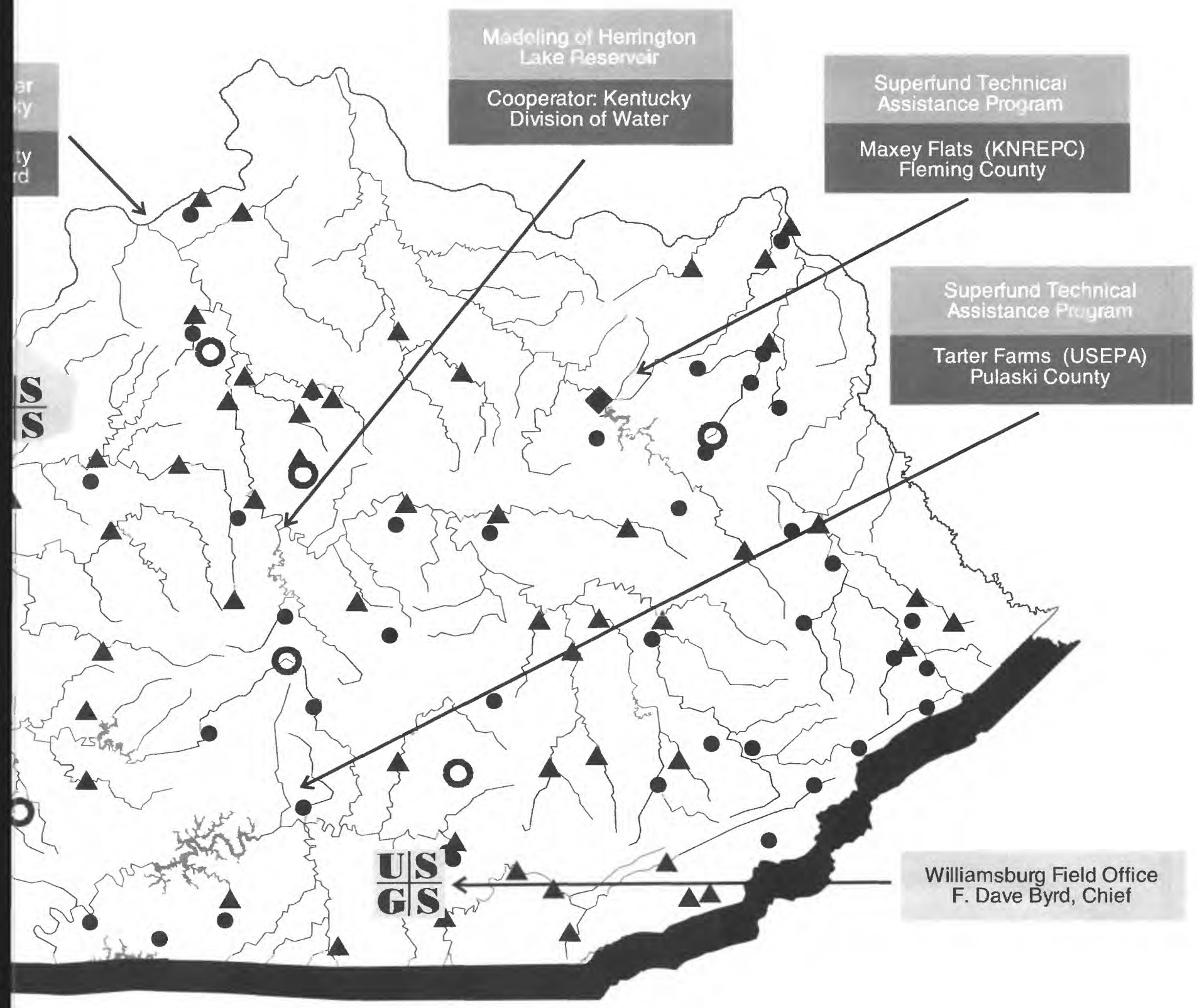

drologic Networks

flow Gage

bservation Well

ty Account Network

Deposition Program

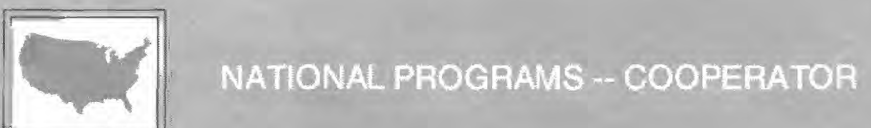

- District Sediment Laboraton -.USGS Districts

- Water Use --Kentucky Division of Water

- Scour at Bridge Foundations-University of Louisville

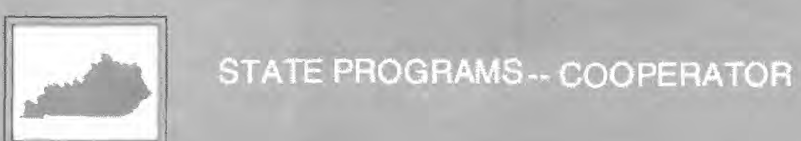

- GIS Dara Base for Hydrologic Research--Kentucky Office for GIS and the University of Louisville

- Hydrologic Assessments at Underground Storage Tank Sites-Kentucky Division of Waste Management 


\section{HYDROLOGIC INVESTIGATIONS}

A wide-ranging program of hydrologic investigations and research provides information essential to the protection and management of the water resources of Kentucky. Investigations cover, to some degree, all aspects of hydrology, water quality, and aquatic biology.

\section{New Programs \\ Modeling of Herringtion Lake Reservoir \\ Cooperator: \\ Kentucky Division of Water}

Purpose: In recent years the Commonwealth of Kentucky has determined that Herrington Lake, an important hydropower, water supply, and recreational reservoir in central Kentucky, is exhibiting characteristics of eutrophic reservoirs (i.e., low dissolved oxygen, algal blooms, taste and odor problems, and occasional fish kills). Sediment is also accumulating in the upper reaches of the reservoir restricting navigation during low-flow periods.

Goals:

- Perform a detailed analysis of the trophic status of Herrington Lake

- Determine the nutrient assimilation capacity of the reservoir

\section{Eeohydrologic Framework and} Ground-Water Flow at the Aaval Surface Warfare Center

\section{Cooperator:}

U.S. Department of the Navy

Purpose: The Naval Surface Wartare Center located in southwest Louisville, Kentucky, is entering a "privatization" phase as part of the U.S. Department of Defense base realignment and closure procedure. An accurate assessment of the geohydrologic framework and ground-water flow system is needed to identify potential pathways for migration of contaminants at the Center before ownership of the property can be transferred to the Lou
isville-Jefferson County Redevelopment Authority

Goals:

- Determine the geohydrologic framework at the Center including depth to bedrock, stratigraphy, and bedrock structure

- Define general ground-water flow patterns, directions, and relation of geology and precipitation to groundwater recharge and movement

\section{Continuing Programs}

Mussel-Monitoring near

Olmsted Locks and Dam Cooperator:

U.S. Army Corps of Engineers

Changes to the sediment regime during the construction and operation of the Olmsted Locks and Dam on the Ohio River could result in water-quality degradation and habitat alteration for a population of endangered orangefooted pearly mussels. The objective of the study is to develop, design, and implement the technology needed to monitor the changes in elevation of the riverbed.

Simulation of Ground-Water Flow In Carroliton, Kentucky

Cooperator: Carroll County Public Water Supply Board

This study has been designed to collect and manage needed data to incorporate into a regionally consistent flow model of the Ohio River alluvium that can be used as the basis for water use and environmental planning.

\section{Scour at Bridge Foundations Cooperator: University of Louisville}

A team of researchers including USGS personnel, the University of Louisville, the University of Minnesota, and the University of Auckland in New Zealand are developing a strategic plan to focus and guide research on streambed scour around bridge foundations.
Assimilation Capacity of

Selected Stream Peaches in Jefierson County

Cooperator:

Louisville and Jefferson County Metropolitan Sewer District

Reaches of the lower Middle and South Forks of Beargrass Creek are studied to assess their assimilation capacity with respect to regions of significant combined sewer overflow inputs.

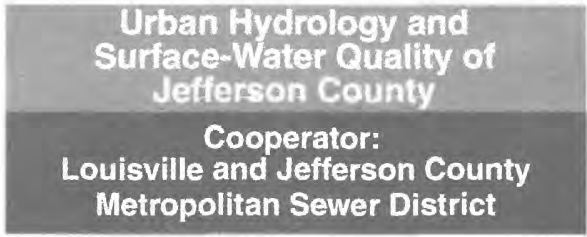

Information is collected on rainfall, streamflow, surface-water quality, and stormwater-runoff quality to assess water-quality conditions and to define long-term trends in water-quality conditions for surface streams in Jefferson County, particularly with respect to land-use practices.

Hydrologic Simulation of the Beargrass Creek Basin

\section{Cooperator:}

Louisville and Jefferson County Metropolitan Sewer District

Changes derived from urban development to the landscape's drainage systems can result in increased flooding, geomorphological alterations of the fluvial landscape, increased water temperatures, and increased loads of pollutants. This study is designed to determine the utility of the Hydrologic Simulation Program-Fortran (HSPF) for the Beargrass Creek Basin of Louisville in enhancing resource management in urban/suburban basins.

Urban Flood Characteristics for Jefferson County

$$
\text { Cooperator: }
$$

Louisville and Jefferson County Metropolitan Sewer District

Urban development generally alters hydrologic response leading to increased rates and volumes of surface 
runoff. The objective of the study is to develop the tools, techniques, and equations needed to determine peakdischarge-frequency estimates for urban basins.

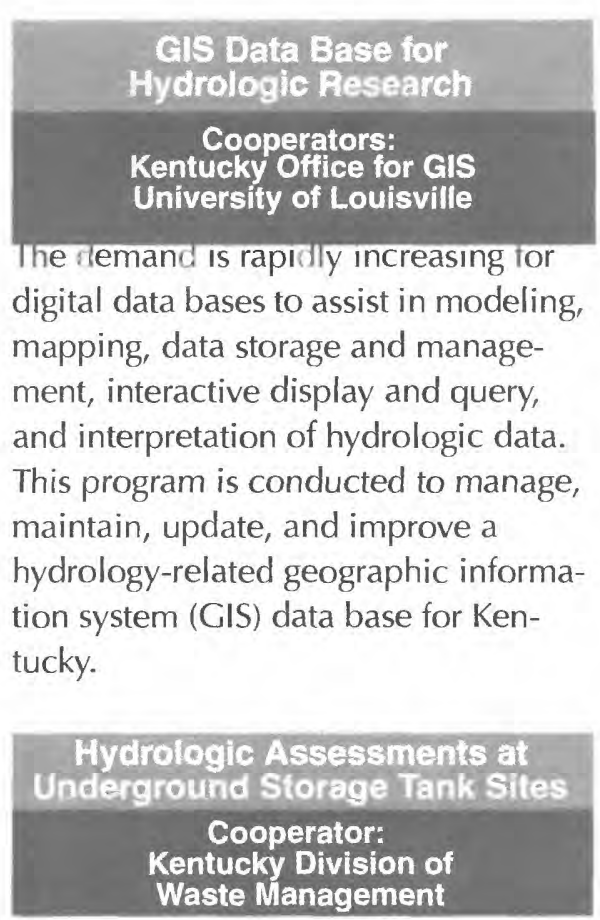

The Kentucky Division of Waste Management (KDWM) has requested technical assistance from the Kentucky District on hydrologic issues related to leaking underground storage tanks. The District provides a wide range of technical support to KDWM while developing technology and applied research concerning hydrocarbons and other chemical contamination of underground storage tank sites.

\section{Superfund Technical} Assistance Program Superfund Sites: Distler Brickyard (USEPA) Maxey Flats (KNREPC) Tarter Farms (USEPA)

At selected sites, the U.S. Environmental Protection Agency (USEPA) and the Kentucky Natural Resources and Environmental Protection Cabinet (KNREPC) have requested technical assistance from the USGS on hydrologic issues. The Kentucky District provides support during the remedial

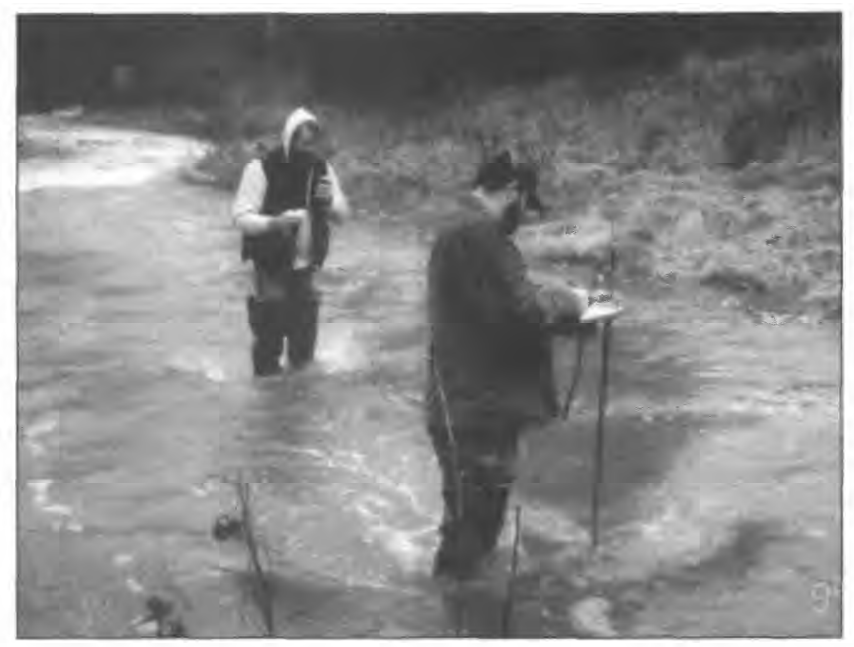

Kentucky District technicians Steve Pickard and Tony Dirrim measured a discharge of 59.4 cubic feet per second (cfs) for Clear Creek in Garrard County, Ky., on February 16, 1995. The normal discharge for this site is less than $1 \mathrm{cfs}$. investigation and remedial action process to the sites listed above.

\section{PUBLIC-INFORMATION AND PUBLIC-SERVICE ACTIVITIES}

Kentucky District staff is involved in numerous other activities in addition to our regular programs of hydrologic-data collection and investigations. Information is provided on a wide range of hydrologic, geologic, geographic, and environmental topics to landowners, water users, public officials, business concerns, professional consultants, and the general public. District staff is also involved in public education, and routinely serve as guest speakers at primary and secondary schools and meetings of public-interest groups, instructors and guest lecturers at colleges and universities, and as science-fair judges.

District staff also routinely serve as members of advisory committees, task forces, and work groups of professional societies and Federal, Commonwealth, or local governmental agencies. Select groups include the following:

- Advisory Committee of the Ohio River Basin Commission

- American Society of Civil Engineers' Task Committee on Bridge Scour
- Committee on Research and Policy of the Kentucky Water Resources Research Institute

- Coordinating Committee for Mammoth Cave Agricultural Nonpoint Source Demonstration Project

- Federal Emergency Management Agency Interagency Flood Assessment Team

- Kentucky Ground-Water Advisory Council

- Kentucky Ground-Water Data Management Committee

- Kentucky Ground-Water Monitoring Guideline Committee

- Kentucky Natural Resources and Environmental Protection Cabinet Scholarship Committee

- Kentucky Rivers Assessment Advisory Committee

- Kentucky Soils Survey Work Planning Group

- Kentucky Water Availability Advisory Committee

- Kentucky Water Interagency Coordinating Committee for Agricultural Nonpoint Source Pollution Prevention

- Nonpoint Source Advisory Committee of the Kentucky Division of Water

- Ohio River Basin Consortium for Research and Education

- Technical Review Committee for the Master Storm Water Management Plan of the Louisville and Jefferson County Metropolitan Sewer District

- U.S. Department of Agriculture Federal Interagency Review Group for Nonpoint Source Demonstration and Hydrologic Unit Projects

\section{...providing Earth Science in the Public Service}


NEW PUBLICATIONS FOR

KENTUCKY, FY 1995-96

\section{Statewide}

Effectiveness of the streamflow-gaging network in Kentucky in providing regional streamflow information, by K.J. Ruhl, 1993: U.S. Geological Survey Water-Resources Investigations Report 93-4106, 28 p.

Flow duration of Kentucky streams through 1990-Historical and monthly flow characteristics, including the effects of reservoirs, by K.J. Ruhl and others: U.S. Geological Survey Open-File Report 95-353, 291 p.

Water-resources data for Kentucky - Water years 1994, 1995 (one volume for each year)

Water use in Kentucky, 1990, by C.J. Sholar and P.A. Wood: U.S. Geological Survey Water-Resources Investigations Report 95-4032, $51 \mathrm{p}$.

\section{Kentucky River Basin}

Comparison of natural and human determinants of phytoplankton communities in the Kentucky River Basin, USA, by R.J. Stevenson and K.D. White, 1995: Hydrobiologia, v. 297, no. 3 , p. 201-216 [Journal article]

Surface-water-quality assessment of the Kentucky River Basin, Kentucky-Fixedstation network and selected waterquality data, April 1987 through August 1991, by M.S. Griffin and others, 1994: U.S. Geological Survey Water-Resources Investigations Report 94-4029, 149 p.

Water-quality assessment of the Kentucky River Basin, Kentucky-Analysis of available surface-water-quality data through 1986, by J.D. Smoot and others, 1996: U.S. Geological Survey WaterSupply Paper 2351-B

Water-quality assessment of the Kentucky River Basin, Kentucky-Distribution of metals and other trace elements in sediment and water, 1987-90, by S.D. Porter and others, 1995: U.S. Geological Survey Water-Resources Investigations Report 94-4134, 184 p.

Water-quality assessment of the Kentucky River Basin, Kentucky - Nutrients, sediments, and pesticides in streams,
1987-90, by K.H. Haag and \$.D. Porter, 1995: U.S. Geological Survey WaterResources Investigations Report 94-4227, $135 \mathrm{p}$.

Water-quality assessment of the Kentucky River Basin, Kentucky-Results of investigations of surface-water quality, 1987-90, by K.H. Haag and others, 1995 U.S. Geological Survey Water-Resources Investigations Report 95-4163, $70 \mathrm{p}$.

\section{Purchase Area}

Geohydrology and simulation of groundwater flow in the aquifer system near Calvert City, Kentucky, by J.J. Starn and others, 1995: U.S. Geological Survey Water-Resources Investigations Report 94-4239, 52 p.

\section{Western Coalfield}

Geohydrology of parts of Muhlenberg, Ohio, Butler, McLean, Todd, and Logan Counties, Kentucky, by J.J. Starn and others, 1993: U.S. Geological Survey Water-Resources Investigations Report 93-4077, 37 p.

\section{Outer Bluegrass}

Use of dye tracing to determine the direction of ground-water flow in karst terrane at the Kentucky State University Research Farm near Frankfort, Kentucky, by D.S. Mull, 1993: U.S. Geological Survey Water-Resources Investigations Report 93-4063, $21 \mathrm{p}$.

\section{Eastern Coalfield}

Summary and interpretation of dye-tracer tests to investigate the hydraulic connection of fractures at a ridge-andvalley-wall site, near Fishtrap Lake, Pike County, Kentucky, by C.J. Taylor, 1994: U.S. Geological Survey Water-Resources Investigations Report 94-4189, 83 p.

\section{Louisville/Jefferson County}

Annotated bibliography of selected references on ground-water resources and geohydrology of the Louisville area, Kentucky, 1944-93, by J.J. Starn and D.S. Mull, 1994: U.S. Geological Survey Open-File Report 94-75, 19 p!

Chemical quality of bottom sediments in selected streams, Jefferson County, Kentucky, April-July 1992, by B.L. Moore and R.D. Evaldi, 1995: U.S. Geological Survey Open-File Report 95-339, 33 p.
Ground-water levels in and pumpage from the alluvial aquifer at Louisville, Kentucky, May 1989-May 1991, by M.D. Unthank and others, 1995: U.S. Geological Survey Water-Resources Investigations Report 94-4099, 2 sheets

Hydrogeology and simulation of groundwater flow in the alluvial aquifer at Louisville, Kentucky, by M.A. Lyverse and others, 1996: U.S. Geological Survey Water-Resources Investigations Report 91-4035, $41 \mathrm{p}$.

Techniques for estimating the quantity and quality of storm runoff from urban watersheds of Jefferson County, Kentucky, by R.D. Evaldi and B.L. Moore, 1994: U.S. Geological Survey Water-Resources Investigations Report 94-4023, $70 \mathrm{p}$.

Yields of selected constituents in base flow and stormflow in urban watersheds of Jefferson County, Kentucky, 1988-92, by R.D. Evaldi and B.L. Moore, 1994: U.S. Geological Survey Water-Resources Investigations Report 94-4065, 70 p.

\section{General}

Design and operation of a system to monitor sediment deposition for protection of an endangered mussel, by M.S. Griffin and D.S. Mueller, 1994: in Fundamentals and Advancements in Hydraulic Measurements and Experimentation, Proceedings of the Symposium, August 1-5, 1994, Buffalo, N.Y.: ASCE, New York, p. 472-481 [Proceedings paper]

Instrumenting flow-control structures with data-collection platforms, by G.K. McCombs and H.A. Hitchcock, 1993: WRD Instrument News, Issue No. 63, December 1993, p. 10-12. [HIF Newsletter Article]

Real-time data collection of scour at bridges, by D.S. Mueller and M.N. Landers, 1994: in Fundamentals and Advancements in Hydraulic Measurements and Experimentation, Proceedings of the Symposium, August 1-5, 1994, Buffalo, N.Y.: ASCE, New York, p. 104-113 [Proceedings paper]

Zebra mussels in the eastern United States, by K.H. Haag, 1994: U.S. Geological Survey Fact Sheet FS 94-014, 2 p. 